\title{
DUKUNGAN AKADEMIK DAN DUKUNGAN SOSIAL SEBAGAI PREDIKTOR NIAT BERWIRAUSAHA MAHASISWA (Studi Pada Mahasiswa Peminatan Kewirausahaan Program Studi S1 Manajemen Fakultas Ekonomi Universitas Tarumanagara)
}

\author{
Hendra Wiyanto \\ Fakultas Ekonomi Universitas Tarumanagara \\ Email: hendrawiyanto@yahoo.com
}

This study was conducted to test the support of academic and social support for entrepreneurial intentions. Samples taken in this study were 60 students from the Faculty of Management Department of Economics, University Tarumanagara through purposive sampling method with sample criteria that students follow entrepreneurship specialization program. The analysis technique used in this study is multiple regression. The findings showed that (1) support the academic and social support jointly significant effect on the intention of entrepreneurship (2) academic support partially does not have a significant impact on the intention of entrepreneurship to students (3) social support partially have a significant impact on entrepreneurial intentions.

Key word: Academic support, Sosial support, Entrepreneurial intention

Penelitian ini dilakukan dengan tujuan untuk menguji dukungan akademik dan dukungan sosial terhadap niat berwirausaha. Sampel yang diambil dalam penelitian ini adalah 60 siswa dari Jurusan Manajemen Fakultas Ekonomi Universitas Tarumanagara melalui metode purposive sampling dengan kriteria sampel yang siswa mengikuti program spesialisasi kewirausahaan. Teknik analisis yang digunakan dalam penelitian ini adalah regresi berganda. Temuan penelitian menunjukkan bahwa (1) dukungan akademik dan sosial dukungan secara bersama-sama berpengaruh signifikan pada niat berwirausaha (2) dukungan akademis secara parsial tidak memiliki dampak yang signifikan terhadap niat berwirausaha (3) dukungan sosial secara parsial memiliki dampak signifikan pada niat berwirausaha.

Kata kunci: Dukungan akademik, Dukungan sosial, Niat berwirausaha

\section{PENDAHULUAN}

Sebagai lembaga pendidikan tinggi, Universitas Tarumanagara memberikan suasana akademik yang kondusif bagi sivitas akademikanya, di dalamnya berlangsung proses pembelajaran yang utuh, baik di kelas, di ruang-ruang seminar bahkan di seluruh lingkungan kampus, tentu saja dengan dukungan fasilitas yang memadai. Dalam suasana akademik yang kondusif maka komunitas akademiknya memiliki ciri khas mengedepankan keberanian yang bertanggung jawab, kebebasan yang didasari nalar yang kokoh, dan terbuka dalam menerima informasi yang diperlukan dengan dilandasi keimanan dan ketaqwaan dalam mengemban amanah Tridarma perguruan tinggi yang meliputi; pendidikan dan pengajaran, penelitian dan pengabdian masyarakat. 
Pelaksanaannya akan berhasil dengan baik, apabila didukung oleh iklim kampus yang kondusif yakni kampus yang bisa memberikan kepastian kualitas hasil belajar dalam suasana yang aman, damai, dan harmonis. Di satu sisi upaya yang dilakukan oleh manajemen kampus untuk menciptakan lingkungan belajar yang harmonis akan tercapai, jika mahasiswa memiliki pengalaman yang menyenang-kan atau telah merasakan kondusifitas kebahagiaan bergaul dalam lingkungan kampus.

Pengalaman beradaptasi dengan lingkungan kampus merupakan dimensi persepsi yang penting, sebab menurut Ivancevic et al. (2006) persepsi adalah proses di mana seorang individu memberikan arti pada lingkungan. Hal tersebut melibatkan pengorganisasian dan penerjemahan berbagai stimulus menjadi pengalaman psikologis. Dengan demikian pengalaman yang positif akan memberikan arti plus pada lingkungan, sebaliknya pengalaman tidak kondusif berpengaruh pada ketidaksetiaan mahasiswa pada lingkungan akademik. Sehubungan dengan semakin pentingnya lingkungan kampus, maka dibutuhkan suatu dukungan kemandirian mahasiswa dalam mensikapi atau bereaksi terhadap berbagai program kampus, termasuk program kewirausahaan untuk mahasiswa yang telah digulirkan sejak tahun 2009. Program ini bertujuan mengembangkan potensi wirausaha muda khususnya mahasiswa, agar kelak setelah menyelesaikan studi mampu men-ciptakan peluang kerja.

Demikian juga dengan program studi S1 Manajemen Fakultas Ekonomi Universitas Tarumanagarayang terus berupaya meningkatkan kegiatan yang terkait dengan kewirausahaan. Warna entrepreneurship menjadi kekhasan dalam program studi ini dengan memberi porsi yang lebih besar dalam perkuliahan. Nilai-nilai entrepreneurship ditanam sejak mahasiswa mulai kuliah hingga menyelesaikan studinya. Perhelatan seminar dan kuliah umum secara terjadwal dengan mengundang para praktisi bisnis yang kredibel di bidangnya akan memberikan corak tersendiri.

Zimmerer (2002:12), menyatakan bahwa salah satu faktor pendorong pertumbuhan kewirausahaan di suatu negara terletak pada peranan universitas melalui penyelenggaraan pendidikan kewirausahaan. Pihak universitas bertanggung jawab dalam mendidik dan memberikan kemampuan wirausaha kepada para lulusannya dan memberikan motivasi untuk berani memilih berwirausaha sebagai karir mereka. Pihak perguruan tinggi perlu menerapkan pola pembelajaran kewirausahaan yang kongkrit berdasar masukan empiris untuk membekali mahasiswa dengan pengetahuan yang bermakna agar dapat mendorong semangat mahasiswa untuk berwirausaha (Yohnson 2003, Wu \& Wu, 2008). Persoalannya bagaimana menumbuhkan niat berwirausaha di kalangan mahasiswa dan faktor-faktor apa yang berpengaruh terhadap niat mahasiswa untuk memilih karir berwirausaha setelah mereka lulus sarjana, masih menjadi pertanyaan dan memerlukan penelaahaan lebih jauh.

Niat berwirausaha akhir-akhir ini mulai mendapat perhatian untuk diteliti karena diyakini bahwa suatu niat yang berkaitan dengan perilaku terbukti dapat menjadi cerminan dari perilaku yang sesungguhnya. Dalam teori planned behavior (Fishbein \& Ajzen, 1985 dalam Tjahjono \& Ardi, 2008) diyakini bahwa faktor-faktor seperti sikap, norma subyektif akan membentuk niat seseorang dan selanjutnya secara langsung akan berpengaruh pada perilaku. Oleh karena itu pemahaman tentang niat seseorang untuk berwirausaha (entrepreneurial intention) dapat mencerminkan kecendrungan orang untuk mendirikan usaha secara riil (Jenkins \& Johnson, 1997).

Dari sejumlah penelitian yang telah dilakukan terhadap niat seseorang untuk berwirausaha, dapat disimpulkan bahwa niat berwirausaha seseorang dipengaruhi 
sejumlah faktor yang dapat dilihat dalam suatu kerangka integral yang melibatkan berbagai faktor internal, faktor eksternal dan faktor kontekstual (Johnson, 1990; Stewart et al., 1998). Faktor internal berasal dari dalam diri dapat berupa karakter sifat, maupun faktor sosio demografi seperti umur, jenis kelamin, pengalaman kerja, latar belakang keluarga dan lain-lain yang dapat mempengaruhi perilaku kewirausahaan seseorang (Johnson, 1990). Sedangkan faktor eksternal berasal dari luar diri yang dapat berupa unsur dari lingkungan sekitar dan kondisi kontekstual.

Literatur kewirausahaan membahas adanya faktor-faktor kontekstual yang membentuk intensi berwirausaha seseorang. Dalam dunia mahasiswa dan perguruan tinggi sebagai penyelenggara pendidikan kewirausahaan, faktor kontekstual ini diterjemahkan sebagai faktor lingkungan di perguruan tinggi yang dapat mempengaruhi intensi berwirausaha pada mahasiswa, meliputi situasi ekonomi, politik, dan budaya di sebuah negara, kompleksitas administrative, akses terhadap sumber daya, serta infrastruktur fisik dan institusional (Kristiansen \& Indarti, 2004).

Penelitian lain dilakukan di dalam negeri yaitu oleh Suharti dan Sirine (2011) dengan hasil bahwa niat berwirausaha dipengaruhi oleh faktor-faktor sikap dan faktorfaktor kontekstual. Faktor-faktor sikap terdiri dari faktor otonomi dan otoritas, realisasi diri, keyakinan, dan jaminan keamanan, sedangkan faktor-faktor kontekstual terdiri dari dukungan akademik dan dukungan sosial.

Temuan dari berbagai studi tentang berbagai faktor yang dapat membentuk perilaku kewirausahaan seseorang semakin jelas memperlihatkan bahwa kewirausahaan seseorang dapat dipelajari dan dibentuk seperti yang disampaikan Johnson (1990). Faktor kontekstual yang cukup mendapat perhatian peneliti adalah dukungan akademik dan dukungan sosial (Gurbuz \& Aykol, 2008). Dukungan akademik (Gurbuz \& Aykol, 2008) diduga merupakan faktor kontekstual yang berpengaruh terhadap niat berwirausaha.

Berdasarkan latar belakang dan urgensi penelitian yang telah dipaparkan di atas, maka penelitian ini difokuskan untuk menguji kembali faktor kontekstual khususnya dorongan akademik dan dorongan sosial secara parsial yang merupakan bagian dari penelitian Suharti dan Sirine (2011) dalam konteks studi pada mahasiswa program studi S1 Manajemen fakultas Ekonomi di Universitas Tarumanagara.

Permasalahan dalam penelitian ini adalah: (1) Apakah dukungan akademik dan dukungan sosial secara bersama-sama memiliki pengaruh terhadap niat berwirausaha mahasiswa?; (2) Apakah dukungan akademik secara parsial memiliki pengaruh terhadap niat berwirausaha mahasiswa?; (3) Apakah dukungan sosial secara parsial memiliki pengaruh terhadap niat berwirausaha mahasiswa?

Tujuan penelitian ini adalah menguji pengaruh dukungan akademik dan dukungan sosial terhadap niat berwirausaha mahasiswa.

\section{TINJAUAN TEORI}

Intensi (niat) berwirausaha. Intensi (niat) berwirausaha adalah intensi (niat) untuk memulai sebuah bisnis baru (Low and MacMillan dalam Pillis dan Reardon, 2007). Kegiatan kewirausahaan pada umumnya sering terjadi karena kesengajaan. Wirausahawan bermaksud untuk mengejar kesempatan, memasuki pasar baru dan menawarkan produk baru. Intentions (minat) menangkap faktor-faktor motivasi yang dapat mempengaruhi perilaku seseorang. Faktor motivasional ini merupakan indikasi seseorang akan seberapa 
keras mereka berusaha dan seberapa besar usaha mereka dalam merencanakan dan melaksanakan perilaku kewirausahaan tersebut. Secara umum, semakin kuat intentions dalam menggunakan perilaku tersebut maka kinerja dalam berusaha akan semakin baik. Individu mempunyai intentions yang kuat untuk mempunyai usaha ketika mereka merasa usaha tersebut ada kemungkinan untuk dikerjakan (feasibility) dan mereka ada keinginan untuk melaksanakan kegiatan usaha tersebut (desirable) (Hisrich, 2008:58).

Dukungan Akademik. Chaplin (2001:495) mendefinisikan dukungan sebagai suatu pengadaan sesuatu hal untuk memenuhi kebutuhan orang lain. Menurut Bandura (dalam Alwisol, 2009), dukungan akademik mengacu pada faktor-faktor yang berkaitan dengan dukungan bagi seorang pelajar untuk mencapai dan menyelesaikan tugas-tugas studi dengan target hasil dan waktu yang telah ditentukan.

Peranan kampus dalam mengembangkan kewirausahaan di kampus dapat dilakukan dengan memberikan dukungan akademik menjadi fasilitator dalam memotivasi, mengarahkan dan penyedia sarana prasarana dalam mempersiapkan sarjana yang mempunyai motivasi kuat, keberanian, kemampuan serta karakter pendukung dalam mendirikan bisnis baru. Selain itu, menurut Yohnson (2003) hal yang harus dipahami oleh pihak kampus adalah pertama, kewirausahaan itu adalah proses, dan kedua, kewirausahaan itu bukanlah suatu kegiatan yang berdiri sendiri melainkan suatu kegiatan berlanjut terus menerus. Jadi kampus perlu mempertimbangkan banyak hal mengenai proses pembelajaran yang berlangsung baik dalam kurikulum maupun metode pembelajaran sehingga mahasiswa mengalami proses dalam mendapatkan pengalaman yang bermakna dan proses tersebut dapat berlanjut pada saat menjalankan bisnis.

Dengan kata lain dukungan akademik dalam kaitan dengan niat berwirausaha adalah suatu dorongan/kondisi yang diberikan dalam kaitan mendukung agar terciptanya niat berwirausaha. Dalam hal ini dukungan akademik dapat melalui pemenuhan sumbersumber belajar, pendampingan mahasiswa serta infrastruktur dalam rangka meningkatkan niat berwirausaha.

Dukungan Sosial. House (dalam Weiten, 1992), mengemukakan bahwa dengan adanya dukungan sosial maka kesejahteraan psikologis seseorang juga akan meningkat karena adanya perhatian, pengertian atau menimbulkan perasaan memiliki, meningkatkan harga diri, serta memiliki perasaan positif mengenai diri sendiri. Dukungan sosial dipahami sebagai adanya relasi yang baik serta munculnya perilaku saling mendukung antar anggota organisasi, seperti berapa banyak individu dalam organisasi tersebut merasa masalah pribadi mereka terbantu untuk penyelesainnya (Salanova, Bakker \& Llorens, 2006). Pengertian lain didapat dari Taylor, Baranowski, dan Sallis (dalam Decloe, Kaczynski \& Havicz, 2009) bahwa dukungan sosial merupakan aksi mendukung/membantu orang lain dalam pencapaian tujuan mereka. Berdasarkan beberapa definisi diatas dapat disimpulkan bahwa dukungan sosial adalah dukungan atau bantuan yang berasal dari orang yang memiliki hubungan sosial akrab dengan individu yang menerima bantuan.

Dukungan sosial merupakan kepercayaan dan ekspetasi seseorang bahwa ia akan mendapatkan dukungan untuk memulai sebuah bisnis baru dari kerabat dekat "belonging group" (orangtua, saudara kandung dan pasangannya) dan dari kelompok "reference" seperti teman, kolega dan dosen (Leon et al., 2007). Dalam dukungan sosial sangat penting dalam menjelaskan perilaku kewirausahaan seseorang. Peneliti seperti Ajzen (1991) dan Alexei et al (dalam Leon et al ., 2007) dalam Theory Of Planned Behaviour 
menjelaskan pilihan dalam berkarir dan dukungan sosial (subjective norms) dapat memprediksi intensi berwirausaha

Terdapat beberapa tipe dari dukungan sosial (Neegaard, Shaw, \& Carter, dalam Rahardjo, Setiasih \& Setianingrum, 2008), yaitu emotional support (terkait pengalaman hidup, perasaan dihargai, pemberian penghargaan, afeksi, rasa percaya dan perhatian), companionship support (membangkitkan suasana hati yang nyaman, pengalihan perhatian dari masalah, berasal dari teman dekat dan tetangga), tangible (or material) support (dukungan biasanya berupa dana, barang, dan kebutuhan yang kongkret), dan informational support (informasi dan pengetahuan yang disediakan guna meningkatkan efisiensi penyelesaian masalah). Dari survey awal peneliti didapati bahwa bentuk dukungan yang ada adalah companionship support yang berasal dari teman (meminta bantuan, belajar bersama, dan diskusi) dan informational support yang juga berasal dari teman, ditambah dengan dosen (bertanya).

Kerangka berpikir. Pertama. Pengaruh dukungan akademik terhadap niat berwirausaha mahasiswa. Dukungan akademik sangat diperlukan dalam mendukung pedidikan kewirausahaan dan tentu saja memiliki pengaruh memperkuat niat berwirausaha pada mahasiswa. Dukungan yang dimaksud adalah terhadap kegiatan yang dilakukan mahasiswa maupun kegiatan yang diciptakan oleh kampus sendiri. Dukungan akademik yang merupakan dukungan universitas terhadap pengembangan kewirausahaan meliputi: dukungan informasional, dukungan emosional, dukungan instrumental, dan dukungan evaluatif. Kedua. Pengaruh dukungan sosial terhadap niat berwirausaha mahasiswa. Azjen (dalam Leon et al., 2007) dalam teorinya menjelaskan pilihan seseorang berkarir di bidang kewirausahaan dipengaruhi oleh dukungan sosial melalui variabel subjective norm. Variabel ini merupakan variabel yang secara signifikan dapat memprediksi niat berwirausaha. Leon et al., (2007) menyatakan dukungan sosial berpengaruh secara signifikan dan positif pada niat berwirausaha. Dukungan sosial ini berasal dari "reference group" (pasangan, orangtua, dan saudara kandung) dan "belonging group" (teman, kolega dan dosen). Sehingga dengan dukungan sosial yang tinggi pada mahasiswa dalam berwirausaha dimungkinkan memperkuat niat berwirausaha pada mahasiswa.

Hipotesis Penelitian. Berdasarkan kerangka teori dan kerangka berpikir yang telah dikaji sebelumnya maka dapat dirumuskan hipotesis penelitian sebagai berikut:

H1 : Ada pengaruh positif dukungan akademik dan dukungan sosial secara bersama-sama terhadap niat berwirausaha mahasiswa.

$\mathrm{H} 2$ : Ada pengaruh positif dukungan akademik terhadap niat berwirausaha mahasiswa.

H3 : Ada pengaruh positif dukungan sosial terhadap niat berwirausaha mahasiswa.

\section{METODE}

Desain Penelitian. Desain penelitian ini adalah explanatory research dengan metode pendekatan kuantitatif dikarenakan data yang diperoleh berupa angka-angka dan analisis menggunakan statistik. Ada pun sifat dari penelitian ini adalah bersifat verikatif, yang pada dasarnya ingin menguji kebenaran dari suatu hipotesis yang dilaksanakan melalui pengumpulan data di lapangan yaitu pengaruh kebenaran akan dukungan akademik dan dukungan sosial terhadap niat berwirausaha mahasiswa (studi pada mahasiswa peminatan 
Kewirausahaan Program Studi S1 Manajemen Fakultas Ekonomi Universitas Tarumanagara).

Populasi dalam penelitian ini adalah seluruh mahasiswa peminatan Kewirausahaan Program Studi S1 Manajemen Fakultas Ekonomi Universitas Tarumanagara semester genap 2013/2014. Pengambilan sampel dilakukan menggunakan metode Purposive Sampling dengan kriteria mahasiswa yang mengambil mata kuliah konsentrasi Peminatan Kewirausahaan pada semester genap 2013/2014. Penelitian ini dilaksanakan di Program Studi S1 Manajemen Fakultas Ekonomi Universitas Tarumanagara dengan waktu penelitian dilakukan kurang lebih selama 6 bulan.

Instrumen Penelitian. Instrumen yang digunakan dalam penelitian ini adalah kuesioner. Menurut Sugiyono (2008) skala likert ini berhubungan dengan pernyataan tentang sikap seseorang terhadap sesuatu. Pengukuran variabel menggunakan skala Likert dengan skor 1 (Sangat Tidak Setuju) sampai dengan 5 (Sangat Setuju). Variabel dukungan akademik diukur menggunakan skala dari Autio et al., 2001 dalam Gurbuz \& Aykol (2008) yang terdiri dari 4 pernyataan, variabel dukungan sosial menggunakan 3 item pernyataan dari skala Gurbuz \& Aykol (2008). Akhirnya, untuk mengukur variabel niat berwirausaha, responden diminta menentukan tingkat ketertarikan mereka untuk mendirikan usaha sendiri setelah mereka lulus sarjana dengan 3 pernyataan yang diadopsi dari Gerry et al. (2008), yang menunjukkan tingkat intensi mereka untuk berwirausaha.

\section{HASIL DAN PEMBAHASAN}

Penelitian ini dilakukan pada mahasiswa program studi manajemen Fakultas Ekonomi Universitas Tarumanagara yang mengambil peminatan kewirausahaan, dengan cara menyebarkan angket kepada para subjek penelitian yang ada. Deskripsi umum subjek penelitian berisi tentang karakteristik subjek penelitian, yaitu jenis kelamin. Adapun perinciannya adalah sebagai berikut:

Tabel 1. Karakteristik subyek penelitian berdasarkan jenis kelamin

\begin{tabular}{ccc}
\hline No & Jenis Kelamin & Frekuensi \\
\hline 1 & Laki-laki & 39 \\
2 & Perempuan & 21 \\
& Total & 60 \\
\hline
\end{tabular}

Sumber : Data primer

Berdasarkan Tabel 1 dapat diketahui bahwa jumlah subjek penelitian adalah sebanyak 60 orang, yang terdiri dari 39 orang yang berjenis kelamin laki-laki atau 65\% dari jumlah subjek penilitian dan 21 orang yang berjenis kelamin perempuan atau 35\% dari jumlah subjek penelitian.

Proses analisis ini adalah cara mendistribusikan/ menguraikan data yang telah disusun ke dalam tabel distribusi frekuensi, sehingga dalam tabel tersebut akan diperoleh hasil mengenai variabel-variabel yang diteliti sebagaimana berikut: Pertama.Variabel dukungan akademik. Untuk mengetahui variabel yang berhubungan dengan dukungan akademik dapat dijabarkan sebagai berikut: 
Tabel 2. Distribusi frekuensi variabel dukungan akademik

\begin{tabular}{ccccccc}
\hline No & Item Soal & \multicolumn{5}{c}{ Frekuensi } \\
& & STS & TS & KS & S & SS \\
\hline 1 & X1.1 & 0 & 3 & 15 & 29 & 13 \\
2 & X1.2 & 0 & 3 & 14 & 32 & 11 \\
3 & X1.3 & 0 & 2 & 13 & 27 & 18 \\
4 & X1.4 & 2 & 11 & 13 & 21 & 13 \\
& Jumlah & 2 & 19 & 55 & 109 & 55 \\
& & $0,83 \%$ & $7,92 \%$ & $22.92 \%$ & $45,42 \%$ & $22.92 \%$ \\
\hline
\end{tabular}

Sumber: Data primer yang di olah

Berdasarkan tabel di atas dan dari 4 item soal yang digunakan untuk mengukur dukungan akademik, dapat diketahui bahwa $0,83 \%$ jawaban responden menyatakan sangat tidak setuju, 7,92\% dari jawaban responden menyatakan tidak setuju, 22.,92\% dari jawaban responden menyatakan kurang setuju, 45,42\% dari jawaban responden menyatakan setuju, dan 22,92\% dari jawaban responden menyatakan sangat setuju. Kedua. Variabel dukungan sosial. Untuk mengetahui variabel yang berhubungan dengan dukungan sosial dapat dijabarkan sebagai berikut:

Tabel 3. Distribusi frekuensi variabel dukungan sosial

\begin{tabular}{ccccccc} 
No & Item Soal & \multicolumn{5}{c}{ Frekuensi } \\
& & STS & TS & KS & S & SS \\
\hline 1 & X2.1 & 0 & 0 & 10 & 25 & 25 \\
2 & X2.2 & 0 & 0 & 10 & 35 & 15 \\
3 & X2.3 & 0 & 0 & 5 & 34 & 21 \\
& Jumlah & 0 & 0 & 25 & 94 & 61 \\
& & $0 \%$ & $0 \%$ & $13.89 \%$ & $52.22 \%$ & $33,89 \%$ \\
\hline
\end{tabular}

Sumber: Data primer yang di olah

Berdasarkan Tabel di atas dan dari dari 3 item soal yang digunakan untuk mengukur variabel dukungan sosial, dapat diketahui bahwa 13,89\% dari jawaban responden menyatakan kurang setuju, 52,22\% dari jawaban responden menyatakan setuju, dan $33,89 \%$ dari jawaban responden menyatakan sangat setuju. Ketiga. Variabel niat berwirausaha mahasiswa. Untuk mengetahui variabel yang berhubungan dengan niat berwirausaha mahasiswa dapat dijabarkan sebagai berikut:

Tabel 4. Distribusi frekuensi variabel niat berwirausaha mahasiswa

\begin{tabular}{|c|c|c|c|c|c|c|}
\hline \multirow[t]{2}{*}{ No } & \multirow[t]{2}{*}{ Item Soal } & \multicolumn{3}{|c|}{ Frekuensi } & \multirow[b]{2}{*}{$S$} & \multirow[b]{2}{*}{ SS } \\
\hline & & STS & TS & $\mathrm{KS}$ & & \\
\hline 1 & Y1.1 & 0 & 3 & 9 & 21 & 27 \\
\hline 2 & Y1.2 & 0 & 2 & 7 & 24 & 27 \\
\hline \multirow{3}{*}{3} & Y1.3 & 1 & 2 & 12 & 18 & 27 \\
\hline & Jumlah & 1 & 7 & 28 & 63 & 81 \\
\hline & & $0,56 \%$ & $3,89 \%$ & $15.56 \%$ & $35 \%$ & $45 \%$ \\
\hline
\end{tabular}


Berdasarkan Tabel di atas dan dari dari 3 item soal yang digunakan untuk mengukur niat berwirausaha mahasiswa, dapat diketahui bahwa $0,56 \%$ jawaban responden menyatakan sangat tidak setuju, 3,89\% dari jawaban responden menyatakan tidak setuju, 15,56\% dari jawaban responden menyatakan kurang setuju, 35\% dari jawaban responden menyatakan setuju, dan $45 \%$ dari jawaban responden menyatakan sangat setuju.

Analisis regresi linear berganda. Pertama. Pengujian asumsi klasik. Pengujian asumsi klasik adalah pengujian yang dilakukan untuk memenuhi asumsi regresi linear berganda. Pengujian asumsi klasik diperlukan untuk memastikan hasil regresi yang digunakan memenuhi asumsi normalitas dan terbebas dari gejala multikolinearitas serta gejala heterokedastisitas. Sehingga model regresi yang digunakan dapat menghasilkan hasil analisis yang dapat diperrtanggung jawabkan dan tidak bias.

Uji normalitas._Uji normalitas dengan kolmogorov-smirnov test dipergunakan untuk mengetahui data yang diuji normal atau tidak.

Tabel 5. Uji Normalitas

\begin{tabular}{llr}
\hline \multicolumn{2}{c}{ One-Sample Kolmogorov-Smirnov Test } \\
\hline $\mathrm{N}$ & & Unstandardized Residual \\
Normal Parameters ${ }^{\mathrm{a}, \mathrm{b}}$ & Mean & 60 \\
& Std. Deviation & .0000000 \\
Most Extreme & Absolute & 1.95052239 \\
Differences & Positive & .079 \\
& Negative & .059 \\
Kolmogorov-Smirnov Z & & -.079 \\
Asymp. Sig. (2-tailed) & & .613 \\
\hline
\end{tabular}

a. Test distribution is Normal.

b. Calculated from data.

Berdasarkan uji normalitas dengan Kolmogorov-Smirnov Test diperoleh nilai KSZ sebesar 0,613 dan Asymp.sig. sebesar 0,846 lebih besar dari 0,05 maka dapat disimpulkan nilai residual telah terdistribusi normal.

Uji multikolinearitas. Uji muktikolinearitas dilakukan dengan menggunakan nilai variance inflation factor (VIF). Model dinyatakan terbebas dari gangguan multikolinearitas jika mempunyai nilai VIF di bawah 10 atau tolerance di atas 0,1 . Berikut adalah uji multikolinearitas dalam penelitian ini.

Tabel 6. Uji Multikolinearitas

Coefficients $^{\mathbf{a}}$

\begin{tabular}{llrr}
\hline & & \multicolumn{2}{c}{ Collinearity Statistics } \\
\cline { 3 - 4 } \multicolumn{1}{l}{ Model } & Tolerance & VIF \\
\hline 1 & (Constant) & & \\
& X1 & .881 & 1.135 \\
& X2 & .881 & 1.135 \\
\hline
\end{tabular}

a. Dependent Variable: $\mathrm{Y}$ 
Berdasarkan output diketahui bahwa: (1) Nilai Tolerance semua variabel independen lebih besar dari 0,10.; (2) Nilai VIF semua variabel independen lebih kecil dari 10,00. Berdasarkan nilai di atas, disimpulkan bahwa tidak terjadi Multikolinearitas.

Uji heteroskedastisitas. Uji heteroskedastisitas dilakukan dengan memplotkan diagram scatlerplot di mana gangguan heteroskedastisitas akan tampak dengan adanya pola tertentu pada diagram. Berikut adalah uji heteroskedastisitas pada model dalam penelitian ini.

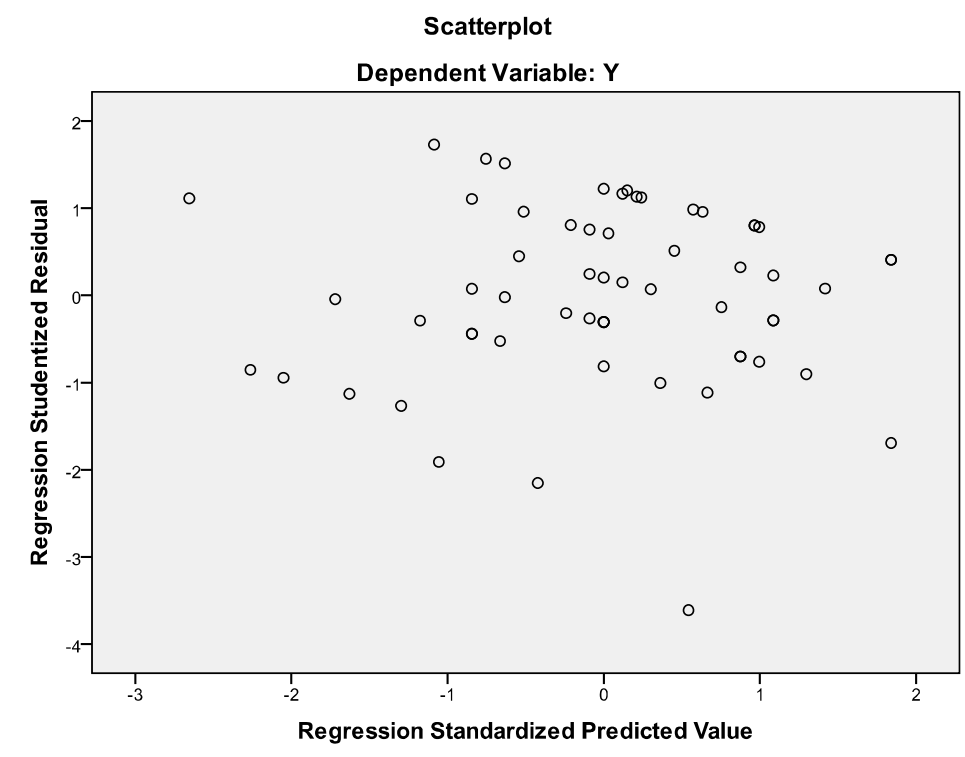

Gambar 1. Uji Heteroskedastisitas

Lihat Grafik Scatter, jelas bahwa tidak ada pola tertentu karena titik meyebar tidak beraturan di atas dan di bawah sumbu 0 pada sumbu Y. Maka dapat disimpulkan tidak terdapat gejala heteroskedastisitas.

\section{Regresi linear berganda}

Tabel 7. Hasil regresi linear berganda

\section{Coefficients $^{a}$}

\begin{tabular}{|c|c|c|c|c|c|c|}
\hline \multirow[b]{2}{*}{ Mode } & & \multicolumn{2}{|c|}{$\begin{array}{c}\text { Unstandardized } \\
\text { Coefficients }\end{array}$} & \multirow{2}{*}{$\begin{array}{c}\begin{array}{c}\text { Standardized } \\
\text { Coefficients }\end{array} \\
\text { Beta }\end{array}$} & \multirow[b]{2}{*}{$\mathrm{t}$} & \multirow[b]{2}{*}{ Sig. } \\
\hline & & B & Std. Error & & & \\
\hline 1 & (Constant) & 6.107 & 1.919 & & 3.183 & .002 \\
\hline & $\mathrm{X} 1$ & .186 & .105 & .228 & 1.771 & .082 \\
\hline & $\mathrm{X} 2$ & .293 & 137 & .274 & 2.131 & .037 \\
\hline
\end{tabular}

a. Dependent Variable: $\mathrm{Y}$

Berdasarkan hasil pada tabel tersebut, dapat disusun persamaan regresi linear berganda sebagai berikut: 


$$
\mathrm{Y}=6,107+0,186 \mathrm{X} 1+0,293 \mathrm{X} 2
$$

Keterangan: $\mathrm{Y}=$ niat berwirausaha mahasiswa; $\mathrm{X} 1=$ dukungan akademik $\mathrm{X} 2=$ dukungan sosial

Dari kedua nilai koefisien pada variabel-variabel independen di atas diperoleh variabel dukungan sosial memiliki nilai koefisien terbesar dengan nilai koefisien 0,293 dibandingkan dengan dukungan akademik. Berdasarkan hasil tersebut diperoleh bahwa variabel dukungan sosial merupakan faktor yang paling dominan yang mempengaruhi niat berwirausaha mahasiswa dalam penelitian ini.

Pengujian hipotesis. Pertama. Uji goodness of fit model. Uji goodness of fit adalah untuk melihat kesesuaian model, atau seberapa besar kemampuan variabel bebas dalam menjelaskan varians variabel terikatnya. Berikut adalah hasil perhitungan nilai $\mathrm{R}$ dan koefisien determinasi dalam penelitian ini:

Tabel 8. Uji goodness of fit model

\begin{tabular}{|c|c|c|c|c|}
\hline \multicolumn{5}{|c|}{ Model Summary } \\
\hline Model & $\mathrm{R}$ & R Square & $\begin{array}{c}\text { Adjusted R } \\
\text { Square }\end{array}$ & $\begin{array}{l}\text { Std. Error of } \\
\text { the Estimate }\end{array}$ \\
\hline 1 & $.412^{\mathrm{a}}$ & .170 & .141 & 1.98445 \\
\hline
\end{tabular}

Tabel tersebut memberikan nilai $\mathrm{R}$ sebesar 0,412 pada model penelitian dan koefisien determinasi sebesar 0,170 . Tampak bahwa kemampuan variabel bebas dalam menjelaskan varians variabel terikat sebesar $17 \%$. Sedangkan sisanya sebesar 83\% dijelaskan oleh variabel lain yang tidak dimasukkan dalam model penelitian ini.

Kedua. Uji F. Uji $\mathrm{F}$ adalah untuk melihat pengaruh variabel bebas terhadap variabel terikatnya. Berikut adalah nilai $\mathrm{F}$ hitung dalam penelitian ini:

Tabel 9 . Uji F

ANOVA $^{\mathbf{b}}$

\begin{tabular}{|c|c|c|c|c|c|c|}
\hline Model & & $\begin{array}{l}\text { Sum of } \\
\text { Squares }\end{array}$ & $\mathrm{df}$ & Mean Square & $\mathrm{F}$ & Sig. \\
\hline \multirow[t]{3}{*}{1} & Regression & 45.932 & 2 & 22.966 & 5.832 & $.005^{\mathrm{a}}$ \\
\hline & Residual & 224.468 & 57 & 3.938 & & \\
\hline & Total & 270.400 & 59 & & & \\
\hline
\end{tabular}

a. Predictors: (Constant), X2, X1

b. Dependent Variable: $Y$

Pengujian hipotesis 1. Tampak bahwa nilai $\mathrm{F}$ hitung pada model penelitian adalah sebesar 5,83 dengan taraf signifikansi sebesar 0,005. Nilai signifikansi adalah di bawah 0,05 yang menunjukkan bahwa variabel bebas secara serempak mempunyai pengaruh yang signifikan terhadap variabel terikat pada signifikansi 5\%. Dengan demikian hipotesis 
H1 dalam penelitian ini yang berbunyi: Terdapat pengaruh signifikan dukungan akademik dan dukungan sosial secara bersama-sama terhadap niat berwirausaha mahasiswa diterima.

Ketiga. Uji t. Uji t (parsial) adalah untuk melihat pengaruh variabel-variabel bebas secara parsial terhadap variabel terikatnya.

Pengujian hipotesis 2. Berdasarkan analisis data di atas, maka tampak pada tabel V. 7 bahwa nilai t hitung untuk variabel dukungan akademik adalah sebesar 1,771. Nilai tersebut di bawah nilai $\mathrm{t}$ tabel untuk $\mathrm{df}=57$ yaitu sebesar 2.00247 sehingga diinterpretasikan bahwa tidak ada pengaruh yang signifikan dari variabel dukungan akademik terhadap niat berwirausaha mahasiswa. Dengan demikian hipotesis $\mathrm{H} 2$ dalam penelitian yang berbunyi: Terdapat pengaruh positif dan signifikan secara parsial dukungan akademik terhadap niat berwirausaha mahasiswa ditolak atau tidak terdukung dalam penelitian ini.

Pengujian hipotesis 3. Berdasarkan analisis data di atas, maka tampak pada tabel V. 7 bahwa nilai t hitung untuk variabel dukungan sosial adalah sebesar 2,131. Nilai tersebut di atas nilai t tabel untuk df $=57$ yaitu sebesar 2.00247 sehingga diinterpretasikan bahwa variabel dukungan akademik mempunyai pengaruh yang signifikan terhadap niat berwirausaha mahasiswa. Dengan demikian hipotesis H3 dalam penelitian yang berbunyi: Terdapat pengaruh positif dan signifikan secara parsial kesiapan instrumentasi terhadap niat berwirausaha diterima.

Berdasarkan analisis data menunjukkan bahwa besar pengaruh dukungan akademik dan dukungan sosial terhadap niat berwirausaha mahasiswa adalah $17 \%$. Dengan demikian dapat dijelaskan bahwa faktor dukungan akademik dan faktor dukungan sosial dapat menumbuhkan niat berwirausaha mahasiswa sebesar $17 \%$ dan selebihnya niat berwirausaha mahasiswa ditentukan oleh faktor lain yang tidak dikaji dalam model penelitian ini.

Hasil pengujian hipotesis menunjukkan dukungan akademik dan dukungan sosial secara bersama-sama berpengaruh signifikan terhadap niat berwirausaha. Namun secara parsial, hipotesis berkaitan dengan pengaruh dukungan akademik terhadap niat berwirausaha mahasiswa tidak terdukung dalam penelitian ini. Hasil penelitian ini. menunjukkan bahwa dukungan kampus dalam sistem pembelajaran yang dapat memotivasi munculnya ide-ide kreatif, penyediaan infrastruktur untuk berlatih kewirausahaan di kampus serta adanya contoh kesuksesan berwirausaha di lingkungan kampus belum dapat meningkatkan niat berwirausaha mahasiswa. Untuk itu universitas haruslah mengambil peran lebih dalam upaya mendukung kegiatan kewirausahaan di kampus. Dukungan yang dimaksud adalah terhadap kegiatan yang dilakukan mahasiswa maupun kegiatan yang diciptakan oleh kampus sendiri. Jadi kampus perlu mempertimbangkan banyak hal mengenai proses pembelajaran yang berlangsung baik dalam kurikulum maupun metode pembelajaran maupun bentuk dukungan akademik lainnya sehingga mahasiswa mengalami proses dalam mendapatkan pengalaman yang bermakna dan proses tersebut dapat berlanjut pada saat menjalankan bisnis.

Sedangkan hipotesis mengenai pengaruh dorongan dari dukungan sosial seperti motivasi dari teman dekat, orang-orang yang dianggap penting serta keluarga ternyata terbukti berpengaruh secara positif terhadap niat berwirausaha mahasiswa. Pengaruh positif tersebut menunjukkan semakin tinggi responden mendapatkan dukungan sosial dari lingkungannya maka akan semakin tinggi intensi berwirausaha. Sebaliknya semakin 
rendah responden mendapatkan dukungan sosial dari lingkungannya maka akan semakin rendah intensi berwirausaha. Oleh karena itu, untuk mendorong timbulnya niat mahasiswa untuk berwirausaha setelah lulus sarjana nanti, perlu mendapat dukungan dari pihak keluarga dan teman-teman terdekat. Dukungan sosial merupakan faktor yang cukup penting dalam mempengaruhi niat berwirausaha. Dorongan berbentuk motivasi yang kuat untuk maju dari lingkungan sosial merupakan modal awal untuk menjadi wirausaha.

\section{PENUTUP}

Simpulan. Dari hasil analisis data diatas, dapat diambil beberapa kesimpulan sebagai berikut: (1) Dukungan akademik dan dukungan sosial secara bersama-sama berpengaruh secara signifikan terhadap niat berwirausaha mahasiswa dengan nilai $\mathrm{F}$ hitung sebesar 5,83 dengan tingkat signifikansi 0,005; (2) Dukungan akademik secara parsial tidak berpengaruh secara signifikan terhadap niat berwirausaha mahasiswa dengan nilai thitung sebesar 1,771 dengan tingkat signifikansi 0,082; (3) Dukungan sosial secara parsial berpengaruh signifikan terhadap niat berwirausaha mahasiswa dengan nilai t hitung sebesar 2,131 dengan tingkat signifikansi 0,037

Saran. Berdasarkan hasil penelitian, dapat disarankan antara lain: (1) Memperhatikan pengambilan data penelitian dengan menggunakan instrumen kuesioner hanyalah menggambarkan pernyataan yang belum tentu menggambarkan kebenaran keadaan diri responden yang sebenarnya, maka dapat disarankan pada penelitian selanjutnya proses pengambilan data perlu memperhatikan situasi dan kondisi responden yang tepat; (2) Bagi para peneliti selanjutnya, peneliti menduga masih terdapat faktor lain yang memungkinkan lebih mempengaruhi niat berwirausaha mahasiswa antara lain: latar belakang bisnis keluarga serta bimbingan karir.

\section{DAFTAR RUJUKAN}

Alwisol. (2009) Psikologi Kepribadian, Edisi Revisi. Malang: UMM Pres

Decloe, M.N. Kaczynski, A.T., \& Havitz, M.E. (2009) "Social participation, flow and situational involvement in recreational phyxical activity". Journal of Leisure Research, 41 (1), 73-90

Gerry. C, Susana. C. \& Nogueira. F. (2008) “Tracking Student Entrepreneurial Potential: Personal Attributes and the Propensity for Business Start-Ups after Graduation in a Portuguese University". International Research Journal Problems and Perspectives in Management, 6(4): 45-53.

Ghozali, Imam. (2006) Aplikasi Analisis Multivariate dengan Program SPSS. Badan Penerbit Undip.

Gurbuz, G. \& Aykol, S. (2008) "Entrepreneurial Intentions of Young Educated Public in Turkey". Journal of Global Strategic Management, 4(1): 47-56.

Hisrich, D.R, Peters, P.M and Shepred A.D. (2008) Entrepreneurship, 7 th ed.New York: McGraw Hil

Ivancevich, John M., Robert Konospaske \& Michael T. Matteson. (2006) Perilaku dan Manajmen Organisasi, Jakarta: Erlangga. 
Jenkins, M. \& Johnson, G. (1997) "Entrepreneurial Intentions and Outcomes: A Comparative Causal Mapping Study". Journal Management Studies, 34, 895-920.

Jogiyanto. (2007) Metodologi Penelitian Bisnis: Salah Kaprah dan Pengalaman. Yogyakarta: BPFE

Johnson, B. (1990) Toward A Multidimensional Model of Entrepreneurship: The Case of Achievement Motivation and The Entre-preneur. Entrepreneurial Theory Practice, 14(3): 39-54.

J.P Chaplin. (2001) Kamus Lengkap Psikologi. RajaGrafindo: Jakarta

Kristiansen, S., \& Indarti, N. (2004) "Entrepreneurial intention among Indonesian and Norwegian students". Journal of Enterprising Culture, 12(1), 55-78.

Leon J.A, Descals, F.J, Dominguez, J.F. (2007) "The Psychosocial Profile Of The University Entrepreneur". Journal of Psychology in Spain, 11(1), 72-84.

Nishanta, B. (2008) "Influence of Personality Traits and Socio-demographic Background of Undergra-duate Students on Motivation for Entrepre-neurial Career: The Case of Srilanka. Paper was presented at the Euro-Asia Management Studies Association (EAMSA)", Conference, Japan.

Pillis, E., and Reardon, K.K. (2007) "The Influence of Personality Traits and Persuasive Messages on Entrepreneurial Intention". International Journal of Entrepreneurial Behavior \& Research, 12 (4).

Rahardjo, L., Setiasih \& Setianingrum, I. (2008) "Jenis dan sumber dukungan sosial pada mahasiswa“. ANIMA Indonesian Psychological Journal, 23(3), 277-286

Salanova, M., Bakker. A. B., \& Llorens, S. (2006) "Flow at work: Evidence for an upward spiral of personal and organizational resources". Journal of Happiness Studies, 7, 122

Santoso, Singgih. (2005) SPSS Mengolah Data Statistik Secara Profesional, Cetakan Keempat, Jakarta: PT Elexmedia Komputindo.

Stewart, W.H., Watson, W.E., Carland, J.C. \& Carland, J.W. (1998) "A Proclivity for Entrepreneurship: A Comparison of Entrepreneurs, Small Business Owners, and Corporate Managers". Journal of Business Venturing, 14(2): 189-214.

Sugiyono. (2008) Metode Penelitian Bisnis, Bandung: CV Alfabeta.

Suharti, Lieli \& Sirine, Hani. (2011) "Faktor-faktor yang Berpengaruh Terhadap Niat Kewirausahaan (Entrepreneurial Intention). Studi Terhadap Mahasiswa Universitas Kristen Satya Wacana, Salatiga”. Jurnal Manajemen dan Kewirausahaan, Vol. 13, No.2, September 2011: 124-134.

Tjahjono, H.K. \& Ardi, H. (2008. Kajian Niat Mahasiswa Manajemen Universitas Muham-madiyah Yogyakarta untuk Menjadi Wira-usaha. Utilitas Jurnal Manajemen dan Bisnis, 16(1): 46-63.

Weiten. W. (1992). Psychology: Theme and variations. (Second ed). California: Books Cole Publishing Company.

Wu, S. \& Wu, L. 2008. The Impact of Higher Education on Entrepreneurial Intentions of University Students in China. Journal of Small Business and Enterprise Development, 15(4): 752-774.

Yohnson. 2003. Peranan Universitas dalam Memotivasi Sarjana Menjadi Young Entrepreneurs. Jurnal Manajemen dan Kewirausahaan, 5(2): 97-111. 
Zimmerer, W.T. 2002. Essentials of Entrepreneurship and Small Business Management. Third Edition. New York: Prentice-Hall. 